International Journal of Linguistics, Literature and Translation

ISSN: 2617-0299 (Online); ISSN: 2708-0099 (Print)

DOI: 10.32996/ijltt

Journal Homepage: www.al-kindipublisher.com/index.php/ijltt

\title{
“Castration or Decapitation?" A Feminist Reading of Two Stories by Angela Carter
}

\author{
Shadi S. Neimneh 8 (iD. \\ Associate Professor of Literary and Cultural Studies, Department of English Language and Literature, The Hashemite University, \\ Jordan \\ $\triangle$ Corresponding Author: Shadi S. Neimneh, E-mail: shadin@hu.edu.jo
}

\begin{tabular}{|c|c|}
\hline ARTICLE INFORMATION & ABSTRACT \\
\hline Received: April 02, 2021 & \multirow{11}{*}{$\begin{array}{l}\text { This article examines two stories by Angela Carter, "The Bloody Chamber" (1979) and } \\
\text { "The Executioner's Beautiful Daughter" (1974) to account for Carter's unique and } \\
\text { ambivalent dismantling of patriarchal myths. Carter conflates two patriarchal tropes, } \\
\text { castration and decapitation, to figure the oppression of women while allowing for an } \\
\text { avenue of resistance. Using the French version of feminism, the work of Hélène Cixous } \\
\text { in particular, the psychoanalytic theories of Freud and Lacan, and the postmodern } \\
\text { critique of Linda Hutcheon, the article contends that Carter uses the trope of } \\
\text { decapitation to link beheading to loss of agency and thus to serve her project of } \\
\text { exposing violent patriarchal and sexual structures. She utilizes decapitation to } \\
\text { interrogate female inferiority and project its castrating impact on those women who } \\
\text { are threatened with this punishment. Decapitation, however, becomes a means of } \\
\text { undermining patriarchal logic from within since Carter reverses its targets and logic } \\
\text { just as she does with castration. Carter's act of conflating castration and decapitation } \\
\text { and unsettling their connotations revises power structures and challenges attributing } \\
\text { castration to men and decapitation to women, offering a postmodern critique of } \\
\text { patriarchal fixities, oppressive boundaries, and negative gender constructions } \\
\text { imposed on women. }\end{array}$} \\
\hline Accepted: May 21, 2021 & \\
\hline Volume: 4 & \\
\hline Issue: 5 & \\
\hline DOI: 10.32996/ijllt.2021.4.5.8 & \\
\hline KEYWORDS & \\
\hline Angela Carter; & \\
\hline Castration/Decapitation; Hélène & \\
\hline Cixous; French Feminism; & \\
\hline Psychoanalysis; British Fiction; & \\
\hline Postmodernism & \\
\hline
\end{tabular}

\section{Introduction}

Decapitation has been used since antiquity as a form of punishment for serious offences against people of high rank or dishonored traitors. Regardless of the time or place of its implementation or its exact means, this punishment has always acquired symbolic, cultural meanings, especially with relation to power structures between the genders. By contrast, castration has been employed since ancient times (especially for guards and servants) to ensure trust in women's areas and loyalty to kings and rulers. Although the renowned British writer Angela Carter (1940-1992) published many novels and stories, the theme of decapitation and its relation to castration is very rarely utilized in her oeuvre. However, it can be seen as part and parcel of her overall feminist project of giving agency to women and rethinking dominant power structures. In one story entitled "The Bloody Chamber" (1979), a woman is threatened with decapitation by her husband because she discovered his bloody past against his previous wives. In another story entitled "The Executioner's Beautiful Daughter" (1974), the actual decapitation of the incestuous brother of a beautiful girl by his father is used to figure the girl's own sexual submissiveness and silence, i.e. her castration. In both stories, hence, Carter tweaks decapitation to serve feminist ends of following patriarchal logic only to subvert it by exposing its injustice to women. She uses the traditional psychoanalysis of Freud against itself and in favor of a subversive poststructuralist, feminist, and postmodernist feminist project that unsettles clear-cut distinctions between "castration" and "decapitation" and treats both sexes as lacking and equally "inferior." To illustrate Carter's project of writing back to the patriarchal canon, it is the son who is literally decapitated and thus symbolically castrated in the story entitled "The Executioner's Beautiful Daughter," not the daughter. In the other story entitled "The Bloody Chamber," the female victim (a young bride) escapes decapitation and the executioner gets killed instead, again symbolically castrated/decapitated, with a bullet in his head. Carter conflates castration and decapitation and makes related images of castration and decapitation a dominant theme in both

\section{K C AL-KINDI CENTER $\mathbf{R}$ D FOR RESEARCH AND DEVELOPMENT}

Your gateway to world-class research

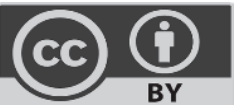

Published by Al-Kindi Center for Research and Development, London, United Kingdom. Copyright (c) the author(s). This open access article is distributed under a Creative Commons Attribution (CC-BY) 4.0 license 
stories to comment on and subvert gender roles and identities. This way, Carter not only rejects harmful stereotypes but also negatively imposed constructions of both genders. Hence, this article attempts an answer to Carter's unconventional treatment of the themes of castration and decapitation.

\section{Literature Review}

Recent feminist readings of Carter's stories have been informed by theories of hermeneutics whereby an attempt is made to interpret her use of the technique of metamorphosis to convey a sense of "postmodern gender equality" via the existence of animal sides to both Carter's male and female characters (Krifa, 2018, p. 57), or Derridean/Lacanian interpretations of the discursive identity formation in stories like "The Bloody Chamber" whereby the protagonist's identity is apparently "a predetermined sign in a signifying loop" she cannot avoid (Mohammadi and Momeni, 2017, p. 32). A study of Carter's collection The Bloody Chamber in light of the theories of Lacan and Zizek argues the "symbolic castration" ensuing because of gaps between character's "true psychological identity and symbolic mask" (Yazdizadeh, 2018, p. 9) in an analysis of three selected stories. However, Yazdizadeh's study of the "hidden psychological significance" of the stories (p. 1) revolves around Lacan's conception of "symbolic castration" as "a radical psychic split" (p. 2) between the real self and one's "symbolic title or mask" (p. 2). In this regard, castration can be understood as the subject's deprivation from identity due to entry to the symbolic realm of language and social norms and thus assuming a symbolic mask or title "in the eyes of the big Other" (p. 2). Yazdizadeh's valuable study is, still, a general Lacanian interrogation of subjectivity and identity-formation in the poststructuralist tradition of the subject's constitution in language.

Many studies on Carter's work focus on thematic ends like the fables and fairy tales Carter subverts. For example, Salman Rushdie summarizes this critical tradition when reminding us that a story like "The Bloody Chamber" offers "a variation on the theme of Beauty and the Beast" (1995, p. xi). Some critics like Gregory Rubinson (2000) have dealt with the depiction of "pornographic" sexuality in Carter's novels by way of "overturning the 'normal' dynamic of sexual relations" (p. 718) via her admiration of the work of Marquis de Sade (p. 719). Hence, Rubinson's study analyzes Carter's novel The Passion of New Eve to argue that she sensibly employs the language of pornography to "rewrite the scripts for traditional gender archetypes" (p. 719). Accordingly, Rubinson's approach is different from the focus of this article, and so is his choice of primary text. However, both articles follow the same line of thought in addressing Carter's rewriting of traditional notions about gender and sexuality.

Another relevant study discusses sartorial imagery and gender roles in Carter's collection entitled The Bloody Chamber (Macsiniuc, 2015). Macsiniuc contends that imagery related to clothes in Carter's stories is used to expose the constructedness and "artificiality" of difference and otherness in gender relations (p. 79). By contrast, this article relies on a different set of images, those related to castration and decapitation, to argue Carter's reaction to the oppression of women, questions of sexual objectification, and the blurring of gender stereotypes. Such thematic, formal, or deconstructionist studies have diverged from the current focus of this article on the interrelationship between castration and decapitation within Carter's revisionist feminist project. While critics of Carter's stories may have examined underlying structures, symbols, and language codes, they have not dealt with castration and decapitation as significant tropes Carter uses/conflates to dismantle patriarchal myths. This article's originality stems from its choice of a novel topic (castration and/or decapitation) and its unique analogical vision in bringing together two stories which were originally published in two different story collections.

One theoretically relevant text in this regard is "Castration or Decapitation?" (1981). In this article, the French critic Hélène Cixous claims that in the course of cultural education women are forced to accept marginalization as expressed in the trope of decapitation: "Women have no choice other than to be decapitated, and in any case the moral is that if they don't actually lose their heads by the sword, then only keep them on condition that they lose them-lose them, that is, to complete silence, turned into automatons" (pp. 42-43; emphasis original). In this patriarchal logic, decapitation threatened by masculine authority is tantamount to silence, peripherality, and submission. Interrogating Freud and arguing the prevalence of the cultural subordination of women in the Oedipal myth, Cixous remarkably explains: "If man operates under the threat of castration, if masculinity is culturally ordered by the castration complex, it might be said that the backlash, the return, on women of this castration anxiety is its displacement as decapitation, execution, of woman, as loss of her head" (p. 43). Carter, like Cixous, questions the position that femininity is culturally structured by decapitation as a displacement for castration complex in men. Carter first confuses castration and decapitation as structuring principles for masculinity and femininity in culture and then reverses them as will be clarified in the following discussion of the short stories.

\section{Research Methodology}

In many works, Sigmund Freud discussed Oedipus complex as an important sexual phenomenon of the early childhood period, explaining how frustrations bring about its dissolution. Castration, for Freud, is essentially fear of loss and emasculation, i.e. the removal of the penis whether real or imagined. Freud (1924) describes this fear of punishment the male child feels: "a threat is pronounced that this part of him which he values so highly will be taken away from him" ("Dissolution," p. 174). This fear of castration is caused by adults (authority figures) and leads to giving up objects of love in a process of identification. Freud 
asserts that the Oedipus complex is triggered by "the threat of castration" ("Dissolution," p. 177). The authority of the cruel father becomes the basis for the working out of Oedipal anxiety, the formation of the super-ego, and the prohibition of incest. Since men view castration anxiety as "fear of demotion to the powerless position occupied by females" (Tyson, 2006, p. 26), they opt for identifying with the male principle while relegating the female principle to a fate of silence and subordination.

The little girl, Freud (1924) contends, upon realizing that she has no penis, "perceives that she has 'come off badly' and she feels this as a wrong done to her and as a ground for inferiority" ("Dissolution", p. 178). The little boy who notices the girl's lack of penis, as Freud explains, wrongly thinks that she has a small one that will grow with time ("Analysis of a Phobia," 1925, p. 11). Accordingly, and in line with the complaint of Cixous that masculinity assigns itself the castration complex leaving the lot of decapitation and mutilation to women, Freud perceives that the Oedipal complex is destroyed in boys because of fear of castration. In girls, this same Oedipus attitude functions adversely because a girl's discovery of her "inadequate" body makes her seek compensation through the father who has what she lacks. Thus, a baby would be "a phallic gift from the father" and repression becomes "a means by which to manage prohibited desires" (Castle, 2007, pp. 165-166). This repression which destroys Oedipus complex is the basis for the formation of the Freudian super-ego.

In "Some Psychological Consequences of the Anatomical Distinction between the Sexes," Freud (1925) argues that little girls fall victims to "penis envy" and inferiority when they notice that a brother or a playmate has what they lack. To make up for that loss, the girl develops a wish for a child that carries the penis. Hence, she sees the father as a love-object and hates the mother as a rival to the father's member. Freud concludes: "As regards the relation between the Oedipus and castration complexes, there is a fundamental contrast between the two sexes. Whereas in boys the Oedipus complex is destroyed by the castration complex, in girls it is made possible and led up to by the castration complex" (emphasis original). Hence, Freudian parlance has made woman lacking and incomplete with relation to man who saves his wholeness via identification with the bearer of the penis, i.e. authority and power. By contrast, castration for women is experienced in terms of penis envy, wounding, scarring, or simply mutilating. Whereas in boys castration anxiety resolves Oedipal complex, in girls it allows for and enhances Oedipal complex. Consequently, for Freud "penis envy is universal in women and is responsible for their 'castration complex', which results in their regarding themselves as 'hommes manqués' rather than a positive sex in their own right" (Selden et al., 2005, p. 129). It is such prejudiced phallocentric castrating logic (men coping with castration anxiety and women being resigned to difference and inferiority) that Carter reacts to, revises, and reverses in the two short stories under discussion in this article.

On the other hand, and away from the somewhat biologically grounded and male-oriented Freudian theories focusing on the penis, the work of French critic Jacques Lacan makes the phallus a signifier of "full presence and power, which, because it is unobtainable, threatens both sexes with the 'castration complex'" (Selden et al., 2005, p. 131). Thus, the phallus as the Name or Law of the father within the symbolic order of language (a system of differences and exclusions) ensures identity and represses incestuous desire. Castration as deprivation is a universal principle because man seeks the wholeness promised by the phallus and woman, not being male, equally desires the phallus. In desiring the phallus, both are "castrated," and man pretends yet never actually possesses the supreme signifier of desire. For Lacan, then, castration can be understood in terms of renunciation of the desire to be the phallus for the mother (the desire of the Other) in return for a fake sense of wholeness. In Écrits, Lacan says that the phallus is a signifier of the desire of the Other/mother: "The phallus is the privileged signifier of that mark in which the role of the logos is joined with the advent of desire" (1989, p. 220). Lacan articulates ambivalent, mutual castration and the pursuit of desire in the following terms:

If the desire of the mother is the phallus, the child wishes to be the phallus in order to satisfy that desire. Thus, the division immanent in desire is already felt to be experienced in the desire of the Other, in that it is already opposed to the fact that the subject is content to present to the Other what in reality he may have that corresponds to this phallus, for what he has is worth no more than what he does not have, as far as his demand for love is concerned because that demand requires that he be the phallus. (1989, p. 221; emphasis original)

While Freud wrote within the patriarchal culture of the late nineteenth century and generally reflected the male-centered logic of his times, Lacan focused on the role played by language in placing us in gender categories and allowing us to negotiate desire and cultural expectations. Freud's unitary approach is countered by Lacan's emphasis on fragmentation, frustrations, and gaps. Lacan's poststructuralist theory on mutual lack of the phallus in male and female children better fits Carter's postmodern fluid model of complicity with and critique of patriarchy and phallocentrism. The fact that castration is universal for Lacan can better help us understand Carter's conflation of castration and decapitation as well as her revision of their cultural significance. Carter averts dichotomous patriarchal logic through her feminist, poststructuralist, and postmodern leanings.

Linda Hutcheon's postmodern theory of "complicitous critique" (1987) will also be used to account for such self-contradictory nature of postmodern writing subverting or contesting what it implies. This vacillating logic can help us, given Carter's feminist 
project, understand the passivity of the executioner's beautiful daughter and her acceptance of illicit sexuality and the young bride's acceptance of conventional gender roles in marriage and fear from patriarchal authority. Countering patriarchy, Carter subverts it from within first by challenging the oppressive Freudian model and then by adopting a more liberal, inclusive, and paradoxical model of postmodernism that allows for wavering and revision (that of French feminism, Hutcheon's "complicitous critique," and the poststructuralist Lacan). While debunking patriarchal myths and decentering established power structures, her stories account for fluid and constructed (rather than fixed) identities, ambivalent desires, and vacillating power structures.

\section{Discussion and Results}

\section{1 "The Executioner's Beautiful Daughter": Reverse Decapitation}

Carter's "The Executioner's Beautiful Daughter" was originally published in her story collection entitled Fireworks: Nine Profane Pieces. It is a gloomy story of guilt, sex, sickness, and sin. In an allegorically unidentified setting, the sullen village mountain dwellers regularly witness barbarous spectacles of death, in particular those of decapitation caused by breaking taboos. In this story, "incest is a capital crime; the punishment for incest decapitation" (p. 40). The dwellers of this mountain village even take public executions to be "the only entertainment the country offers" (p. 35). The poor, pale man to be executed when the story opens is twenty years old and is Gretchen's, the beautiful daughter's, own brother. The fate of symbolic decapitation Cixous has tackled in her article is reversed here and carried out against a male victim. The decapitation scene Carter describes involves one fatal blow rather than elaborate torture preceding beheading:

The victim kneels and lays his neck upon the block. Ponderously, the executioner lifts his gleaming steel. The axe falls. The flesh severs. The head rolls. The cleft flesh sprouts its fountains. The spectators shudder, groan and gasp. And now the sting band starts to bow and saw again whilst a choir of stunted virgins, in the screeching wail that passes for singing in these regions, intones a barbaric requiem entitled: AWFUL WARNING OF THE SPECTACLE OF DECAPITATION. (pp. 36-37; emphasis original)

Surprisingly, the executioner is the father, and the victim is his own son who committed incest. It is the patriarch who guards the law of decapitation, a terribly broad and huge man who is more than six and a half feet high who has become "an object who punishes" as well as "an object of fear." He is "the image of retribution" (p. 36). In this regard, decapitation is the "real" enactment of castration complex. The fear of losing the male member (castration anxiety) becomes actually the loss of one's head, and masculinity is apparently ordered in this mountain village by decapitation rather than castration threat. Or rather, decapitation is the ultimate form of castration. The crime of brother/sister incest is punished by the village executioner in the act of beheading his own son, which casts the father in the role of the sexually jealous primal father in a primitive horde. The choir of "stunted" virgins and the band are reminiscent of the chorus of a Greek tragedy, observing or commenting on the events but not able to divert the unfolding tragic action. They also hint at the perverted sexuality taking place at the family level in this small community.

Echoing Freudian thought on the Oedipus complex, Lacan (1977) in "The Meaning of the Phallus" argues that in the primordial law "castration should be the punishment for incest" (p. 1149). The father's decapitating of the incestuous son who desires the mother/daughter is alternatively a form of castration for incestuous desires. However, diverging from Freud's somewhat biological emphasis on the male organ, Lacan extends the signification of the phallus to the desire of the Other and language ( $p$. 1154). In Carter's fictional world, castration and decapitation become conflated. Or rather, Carter revises the cultural foundations of masculinity and femininity to alleviate the oppression befalling women. Carter's male victim is effeminized as thin, pale and graceful (p. 36), passively accepting the instantaneous punishment of decapitation with a sharp sword. The aggressor, the victim of decapitation, is thus a male character. Within the story's symbolic frame, the act of decapitation transfers the punishment from one body part (the male member) to another (the sexual violator's head) while also instilling another form of castration (i.e. fear) in the spectators of punishment as well as the sexually violated victim.

Talking about a shift in the penal system in Europe occurring at the end of the $18^{\text {th }}$ century and early in the $19^{\text {th }}$ century, Michel Foucault in Discipline and Punish (1977) considers the disappearance of the public spectacle of torture and the body "as the major target of penal repression" (p. 8). The elaborate theatrical torture was replaced by a system of "constraints and privations, obligations and prohibitions" (p. 11) in order to avoid cruel forms of execution. In decapitation through the guillotine, in particular, Foucault observes, "Death was reduced to a visible, but instantaneous event. Contact between the law, or those who carry it out, and the body of the criminal, is reduced to a split second" (p. 13). One blow in one moment becomes the goal of execution rather than torture touching the body before a public execution. Punishment, Foucault contends, becomes a means of addressing the soul of the victim and denying them "the right to exist" (p. 13). The guillotine fulfills this function and has "the abstraction of the law itself" (p. 13). Foucault's description exactly fits what happens in Carter's story. The aggressor becomes the site for implementing the patriarchal law of the father ("whose word is law" p. 37) who immediately punishes incest, and actual decapitation is symbolically castration for the male aggressor. One blow asserts the father's dominance over the aggressor. The passive, silent sister plays not only the role of the victim but also the bearer of the brunt of decapitation/castration. However, she is spared the actual violence of castration (since she is already a "castrated" woman lacking the sexual anatomy of men in 
patriarchal terms) and equally the violence of decapitation (as the beautiful yet weak victim of sexual imposition). Nevertheless, Gretchen is made to witness this "visible" and immediate Foucauldian punishment on the aggressor's body and thus psychologically experience the castrating impact of decapitation as well as the renewal of the father's authority.

Gretchen, the beautiful daughter, is glorified and described as the one "on whose cheeks the only roses in these highlands grow" (p. 37). The roses signify the virginity and innocence she has carried and lost at the hands of a brother and a perverse father who wears the executioner's mask. In an environment of disease and freezing weather, Gretchen is remarkably beautiful yet sexually objectified, as suggested by the narrator's description of her doing domestic tasks for her father against an environment of depravity and filth: "In this museum of diseases, the pastel beauty of Gretchen, the executioner's daughter, is all the more remarkable. Her flaxen plaits bob above her breasts as she goes to pluck, from their nests, the budding eggs" (p. 38). She lives in an environment of broken taboos and transgressions, and the sexual objectification hinted at previously becomes more manifest in such a description:

Daily their minds are terrified and enlightened by the continuous performances of apocalyptic dirges for fornicating siblings and only the executioner himself, because there is nobody to cut off his head, dare, in the immutable privacy of his leathern hood, upon his blood-bespattered block make love to his beautiful daughter. (p. 40)

The father's ability to decapitate sexual rivals and spare himself a possible castration ensures his sexual manipulation of his passive daughter. Gretchen, who is described the only pure and pretty "flower" of the mountains, tucks up her "white" apron and skirts "so they will not crease or soil but, even in the last extremity of the act, her father does not remove his mask for who would recognize him without it?" (p. 40). This solitary power the father exercises on his daughter is nothing but sexual subjugation. The pliant victim falls in the role of the oppressed "subaltern" who can neither speak nor get heard, thus getting consigned to an inevitable silence and marginalization. In this regard, Spivak's famous declaration about the muted subject as the subaltern woman is the following: "If, in the context of colonial production, the subaltern has no history and cannot speak, the subaltern as female is even more deeply in shadow" (1988, p. 2203). Since Gretchen does not resist this sexual manipulation of her at the hands of her brother and father, she is yet passively complicit in her subjugation. And while a colonial context is missing here, the same dynamics of power relations apply. The executioner and his beautiful daughter are both trapped in their sexual and cultural stereotypes. Gretchen is doubly "colonized" by the patriarchal authority of her father as well as his sexual manipulation of her body.

As a terrible patriarch, the father bears and brandishes his axe in his hands in the manner he carries his male member: "He brings one booted foot to rest on the grim and sacrificial altar which is, to him, the canvas on which he exercises his art and proudly in his hand he bears his instrument, his axe" (pp. 35-36). The axe is an evident phallic symbol, and so are the snake Gretchen discovers in the sewing machine on the night of her brother's death and the bicycle on which her brother rides in her dreams. Gretchen's dreams (with their phallic symbolism) might suggest her guilt and her complicity in the breaking of sexual taboos. The wooden block on which beheading is performed acquires the color black after years of receiving victims' blood, which indicates repeated acts of decapitation as well as the supreme authority of the oppressive father. Against Gretchen's delicate nature, her father is made the abominable patriarch parasitically living off potential life. This man "whose word is law" eats no egg that does not have inside it "a nascent bird" (p. 37). The executioner is imprisoned in his own perversities, and the mask he constantly wears is an "artifice" (Macsinuic, 2015, p. 86), an indication that he "performs" or masquerades his otherwise unsecure gender identity to ensure patriarchal control over his victims. While he decapitates his son for incest, he commits the same sin with impunity because he is "the law." In this regard, the law of the father is repressive, enforcing separation from the object of incest (i.e. the mother or the daughter in this particular case) and subsequent punishment. The father's castrating sword, so to speak, decapitates the son as a sexual rival to ensure full sexual access to the beautiful daughter. It is the silent woman, not a man, who functions under the threat of castration (and thus symbolic decapitation) as silence and inferiority because literal decapitation (and thus symbolic castration) becomes the man's unexpected lot.

The executioner commits incest in the courtyard "upon the block where he struck off the head of his only son" (p. 40). The site of reverse decapitation equally becomes the site of sexual violation. The father's sexual exploitation of his daughter is contingent on castration threat and decapitation. On the other hand, the daughter's pliant nature makes her complicit in her oppression. Carter's critique of patriarchy ambivalently carries the seeds of complicity with traditions of suppression. The male aggressor gains in power at the expense of the silent, complicit daughter. While the executioner's son is literally decapitated and symbolically castrated, his passive daughter is symbolically decapitated and castrated due to her sexual compliance. The daughter is not already castrated as per Freudian logic. Rather, she is made so at the hands of her father. Her sexual subjugation and her silencing by male power conflate castration and decapitation and make her a victim of both. 


\section{2 "The Bloody Chamber": Abortive Decapitation}

While "The Executioner's Beautiful Daughter" makes the son, rather than the daughter, the victim of decapitation, "The Bloody Chamber" aborts this very act and symbolically transfers it to the husband who unavailingly tries to decapitate his wife. Thus, Carter's story (originally published in the collection entitled The Bloody Chamber and Other Stories) reverses traditional, patriarchal expectations concerning violence and ultimate victimization. Commenting on another story by Carter, "The Erl-King," Rodriguez-Salas has argued that the female protagonist is presented as one in a process of "acquiring her own voice and identity in her refusal to become the Erl-King's object of desire" (2010, p. 225). In "The Bloody Chamber," the protagonist achieves this independence with the help of her mother, refusing to be victimized by a Marquis who embodies the cruel patriarch. The story is based on the Bluebeard folktale motif, with a rich man successively murdering his numerous wives. The narrator is a pianist, a virgin of seventeen years leaving the Paris of her childhood and her mother to the realm of marriage in her husband's gothic castle. This young bride gets married to the Marquis who had been married multiple times in the past. However, his wedding gift to her foreshadows his attempted decapitation of her at the end of the story and his patriarchal control over her: "His wedding gift, clasped round my throat. A choker of rubies, two inches wide, like an extraordinarily precious slit throat" (p. 114). The present in the form of a "choker of rubies" not only predicts blood and death but also makes the bride think of the red ribbon on the neck of those who barely missed being decapitated by a guillotine (Laurens, 2014). The young bride (who is also the narrator) says: "the aristos who'd escaped the guillotine had an ironic fad of trying a red ribbon round their necks at just the point where the blade would have sliced it through, a red ribbon like the memory of a wound" (p. 115). The crimson color of the jewels round the young bride's neck reminds her of blood and slitting, which suggests the unavailing decapitation her husband would try on her toward the end of the story and makes her story a survivor's narrative of elaborate "beheading." On the other hand, the Marquis's other gift, a painting for Saint Cecilia, is another symbolic gift associated with the bride's virginity and possible immolation in fire or by the executioner's sword. The patroness of music in the religious romance finds parallel in this story in pianist heroine who is saved from decapitation by her innocence and the heroic intervention of her mother.

Before he deflowers her, the Marquis ironically makes his bride put on her ruby necklace, that choker, that "family heirloom of one woman who had escaped the blade" (p. 121), as if predicting the failure of his attempted decapitation of her while drawing on a patriarchal family tradition of violently suppressing women. As with other Carter stories, this image of victimization targets the female head as the locus of power and potential. Significantly, the suffocating constraints of patriarchy alluded to remind us of the "trusting" bird victims of the Erl-King, in Carter's story of that title, with wedding rings round their necks and the sharp teeth of the King leaving love bites on the girl narrator: "you sink your teeth into my throat and make me scream" (1979, p. 190). In both cases, male violence targets the upper part of the body (the head) and suggests the figurative meanings of decapitation: negation, silencing, and loss of agency. As a trope, decapitation is tantamount to symbolic castration. Both are metaphors for lack of agency and disempowerment.

The fact that the Marquis objectifies his bride is evident when she says that he had invited her "to join this gallery of beautiful women" (p. 114) and when he observes her through the multiple mirrors in his room "with the assessing eye of a connoisseur inspecting horseflesh, or even of a housewife in the market, inspecting cuts on the slab" (p. 115). He makes her and other women the object of his voyeuristic male gaze, thus highlighting the exhibitionism to which the female body is subjected. Her musical talents become a way out of this restrictive marriage, yet her entanglement in this bizarre relation is difficult to avoid. For instance, his library books that she inspects hint at his sexual perversity, sadism, and violence with pictures of naked women, masturbating men, and immolated wives. As in "The Executioner's Beautiful Daughter," the major male figure holds patriarchal attitudes and acts accordingly.

When he temporarily leaves to America, she explores the castle searching for his real life, soul, and identity. Her discovery is that for her husband sex/love is never separated from torture. Her own pain of defloration comes to her mind as she explores her husband's dark torture room and reads everywhere the signs of his violence against his ex-wives: "Absolute darkness. And, about me, the instruments of mutilation" (p. 131). Emotionally encouraged by her mother's defiant personality and strong will, she moves to discover the tortured bodies of his late wives. On the embalmed corpse of one victim, an embalmed opera singer, the narrator observes the imprint of the strangler's finger on her throat (p. 131). Significantly, strangling this female victim from her throat is a punishment that targets the head first, which links it to decapitation. The disembodied skull she finds is another relevant point because in the darkness the skull seems to hang away from its skeleton and cords, which again conjures the image of a decapitated head. In addition to the emotional and spiritual encouragement the narrator receives from her mother, her music talent seems to be another empowering outlet.

The blind piano-tuner who comforts her and who is kind to her, upon her confiding to him what she saw, tells her about strange tales people down the coast share featuring a Marquis hunting young women with dogs as if they were foxes, a clear image of objectification, and then decapitating them. Being blind, the piano-tuner is figuratively castrated like Oedipus putting out his 
eyes after the discovery of his incestuous past and like Tiresias the blind seer in classical mythology with an ambivalent sexual nature. The piano-tuner and the young bride he comes to gradually help and love are castrated in one way or another (with castration understood in terms of lack and disempowerment). They are both pitted against the Marquis brandishing his sword and threatening those who oppose him with decapitation. The story told by the piano-tuner turns out to be another version of patriarchal decapitation: "My grandfather had it from his grandfather, how the Marquis pulled a head out of his saddle bag and showed it to the blacksmith while the man was shoeing his horse" (p. 135). Surprisingly, the head turns out to be that of the blacksmith's wife. Decapitation in this story serves the function of objectification and additionally hints at the possible fate of the bride. Unlike "The Executioner's Beautiful Daughter," this story aligns decapitation with women. However, the end of "The Bloody Chamber" will abort such an association through saving the female protagonist from decapitation and symbolically castrating/decapitating her husband.

The turning point comes when the husband is suddenly called to attend to some business in America, and his New York agent calls him accordingly. He trusts his wife with his keys, asking her not to use one specific key. He thus leaves her on her wedding night with a sense of curiosity as to the secrets this room hides. The climax occurs upon his discovery of her entry into his bloody chamber; as a result, he asks her to get ready for martyrdom due to her disobedience. Significantly, when she asks about the form and nature of the punishment, he replies in an authoritative tone indicative of his presumed privileged possession of the symbolic order of language: "'Decapitation,' he whispered, almost voluptuously. 'Go and bathe yourself; put on that white dress you wore to hear Tristan and the necklace that prefigures your end. And I shall take myself off to the armoury, my dear, to sharpen my great-grandfather's ceremonial sword."' (p. 139). The sword is a supreme phallic symbol in Freudian parlance, a boon associated with a patriarchal legacy inherited from the Marquis's father and grandfather. It is used here as an instrument of decapitation, and thus castration in the sense of loss of power on the part of the victim. And so are the phallic white lilies surrounding her marital bed, writhing like snakes, and shooting upward. The red mark on her forehead (the heart-shaped stain of blood on the key that transferred itself to her forehead) is symbolic of the sacrifice to take place and the sin of disobedience she committed like Eve. It makes her think of "the caste mark of a Brahmin woman. Or the mark of Cain" (p. 139). Hence, the narrator thinks of her expected gendered murder in terms of ritualistic sacrifice, guilt, and banishment. The necklace she wears has phallic connotations too, being compared to a snake coiled and ready to strike (p. 140). Against the agency assumed by the husband, the bride is expected to accept the severe punishment of decapitation, which is a dishonorable form of death historically practiced on some traitors. The intended beheading is, hence, a gendered act of dehumanizing the bride.

While the masked executioner hides his true identity from the dwellers of the highlands and his daughter in the first story, the Marquis in this story seems to be another masked man. His bride thinks that she glimpsed his real face without its mask only in the storm of orgasm (p. 121). Both men resemble the masked torturer for whom the act of love does not exactly differ from the infliction of pain. The bride recounts how her husband initiated the sacrificial rites: "My husband laid my branded forehead on the stone and, as he had done once before, twisted my hair into a rope and drew it away from my neck" (p. 141). Like the executioner's son in the other story, she puts her head on the mounting block, passively getting ready for execution. However, the sudden arrival of her mother on a wild horse saves her from the sword and aborts the act of decapitation: "The blade did not descend, the necklace did not sever, my head did not roll" (p. 142; emphasis original). The husband's indecision (standing "transfixed, utterly dazed, at a loss" p. 142) allows the young bride to escape death. She is saved from decapitation by the Medusa-like figure in the person of her mother, "her hat seized by the winds and blown out to sea so that her hair was her white mane, her black lisle legs exposed to the thigh, her skirts tucked round her waist, one hand on the reins of the rearing horse while the other clasped my father's service revolver" (p. 142). The mother, a strong-willed wife of a late soldier, enacts a reverse form of castration, shooting the Marquis in the head. In this case, he is also decapitated in the sense of losing power over his bride. And the Medusa-like mother suggests the Medusa of the Greek myth as the hideous Gorgon with snakes for hair and turning those who gaze at her eyes into stone. In some versions of the classical myth, Medusa gets decapitated by Perseus with the help of Athena. The bride says: "And my husband stood stock-still, as if she had been Medusa, the sword still raised over his head as in those clockwork tableaux of Bluebeard that you see in glass cases at fairs" (p. 142). In other words, the Medusa head with living snakes turning men into stones, i.e. paralyzing them, is an image of castration. The man who threatens to decapitate his wife but fails becomes symbolically castrated in not being able to act and symbolically decapitated in being shot in the head. Carter blurs and transgresses oppressive gender distinctions as a fluid artifice (Macsinuic, 2015, p. 83), which is in line with the postmodern feminist orientation of many of her stories.

However, the petrifying image of the decapitated Medusa head functions ambivalently, signifying and bestowing castration. In "Medusa's Head," Freud (1940) relates and interprets the Medusa myth in terms of the castration complex. The gorgon's head turns the stiff viewer to stone: "Observe that we have here once again the same origin from the castration complex and the same transformation of affect! For becoming stiff means an erection. Thus in the original situation it offers consolation to the spectator: he is still in possession of a penis, and the stiffening reassures him of the fact" (p. 273). Freud means that the sight of female genitals causes the fear of castration. The multiple snakes on a severed head, acting as penis symbols, indicate the 
possession of none, and thus confirm Medusa's castration. In Carter's story, this representation of a castrated woman in the image of the Medusa-like mother first frightens/castrates the male aggressor with her black skirts tucked up around her waist so she could ride hard, her white hair, and her horse neighing frenziedly (p. 142). In addition, she figuratively decapitates him by shooting him in the head. The revolver the mother carries is another phallic symbol. The sexual master is thus reduced to a pauper as the end of the story reveals: "The puppet master, open-mouthed, wide-eyed, impotent at the last, saw his dolls break free of their strings, abandon the rituals he had ordained for them since time began and start to live for themselves; the king, aghast, witnesses the revolt of his pawns" (p. 142). The traditional gender roles indicated by Carter's analogy of "puppet master" and pliant "dolls" are subverted. In the case of the Marquis, the stiffness contingent on the sight of the Medusa head is rendered as a fake "erection" and is expressed in terms of loss, dismay, and surprise. The Marquis stands transfixed. The ensuing "stiffness" belies nothing but "impotence" in the face of the approaching mother. While the Marquis loses his phallic power in this encounter, it is the protagonist's mother who becomes the virago, the Amazonian mother who disrupts gender boundaries.

Once again, Carter challenged dominant power structures between men and women through the unorthodox ending of her story in which the patriarch is made the victim of matriarchy. Nevertheless, the overall frame of the story is conventional when it comes to the actions preceding the unexpected end. Right from the start, the teenage bride has accepted a traditional life of marriage to a potent man and conceded to yield to his sexual and financial authority over her. In both stories, Carter follows the postmodern model of complicity with patriarchy and critique of its stratagems via subverting the castration/decapitation dichotomy. The complicity of the executioner's daughter and the young bride in their oppression counters the revolutionary model provided by the mother in "The Bloody Chamber" and establishes an ambivalent case of complicity with and critique of traditional gender roles.

In "The Laugh of the Medusa," Cixous (1976) encourages women to write and embrace writing as a means of self-expression from which they have been driven away just as they have been estranged from their bodies by patriarchal law and marginalization. She famously asks and asserts: "And why don't you write? Write! Writing is for you, you are for you; your body is yours, take it" (p. 876). For Cixous, writing is a means of making women heard and endowing them with a voice against phallocentric ideologies: "It is by writing, from and toward women, and by taking up the challenge of speech which has been governed by the phallus, that women will confirm women in a place other than silence" (p. 881). Likewise, Carter writes two stories which thematically challenge patriarchal law and simultaneously give her an avenue of self-expression against oppressing women. Her stories are subversive of patriarchal ideologies, forcing us to reexamine and revise fixed notions about gender roles. However, and in order not to replace patriarchy with another structure of oppression, Carter allows for female desire and complicity. Thus, her fiction interrogates feminist, postmodern, and poststructuralist dynamics of ambivalence.

Discussing the value of the phallus for men and the fear of being (castrated) women, Cixous (1976) contends that phallocentric ideologies wrong both women and even men in affirming the primacy of the phallus, forcing men to be reduced to that signifier and women to eternally mourn its loss: "As a woman, I've been clouded over by the great shadow of the scepter and been told: idolize it, that which you cannot brandish. But at the same time, man has been handed that grotesque and scarcely enviable destiny (just imagine) of being reduced to a single idol with clay balls" (p. 884). Hence, Cixous uses the mythical figure of the hideous Medusa to describe fear of castration and to reverse this phallocentric logic by asking us to imagine a beautiful laughing Medusa. Laughter becomes a trope for subversion, and we can imagine the bride's wild mother in Carter's story laughing in triumph after killing the Marquis and freeing her daughter from decapitation. Cixous (1976) equates decapitation with castration and argues that women are not afraid of being anonymous in the way men are afraid of castration, i.e. losing the "head" of a body or body part: "woman couldn't care less about the fear of decapitation (or castration), adventuring, without the masculine temerity, into anonymity, which she can merge with without annihilating herself: because she's a giver" (p. 888). This defiant attitude indicates a reversal of power relations with the fear of decapitation and castration being a myth constructed to serve crude power interests. In subjecting men to the dangers of symbolic or actual castration and decapitation, Carter forces us to rethink gender relations and patriarchal discourses. Therefore, her overall feminist project is revisionary rather than conciliatory, taking dominant cultural myths like those about castration and decapitation and turning them upside down while showing awareness of social limitations and women's role in their own subjugation.

\section{Conclusion}

Carter revises patriarchal discourses on castration and decapitation, unsettling, reversing, and confusing them. In "The Executioner's Beautiful Daughter," she makes a man the victim of decapitation and makes the subservient woman a case of symbolic castration. In "The Bloody Chamber," she saves the woman from decapitation and allows the victim's castrated/decapitated Medusa-like mother to shoot (i.e. symbolically castrate and decapitate) the threatening husband in the head. Like poststructuralist and French feminists, Carter has used castration/decapitation as a figure for oppression. However, she has subverted such masculine tropes to overthrow patriarchal logic and thus expose sexual violence. It may not be apt to argue that Carter pursued a feminine style of writing that counters patriarchal discourse. Écriture feminine advocated by French 
feminists as a fluid associative mode close to the female body and countering the organized rationalist language of patriarchy is not exactly present, and both stories seem to follow a traditional narrative style and a chronological plot structure. However, it is legitimate to argue that Carter uses form and content in line with ambivalent postmodernist ends as set forth by Linda Hutcheon (1987) in her definition of postmodernism in art as "a fundamentally contradictory enterprise" that installs and then subverts convention in ironic ways, offering "a model that works from a position within both and yet within neither, a model that is profoundly implicated in, yet still capable of criticizing, that which it seeks to describe" (p. 180). Hutcheon's theory of "complicitous critique" accounts for such self-contradictory nature of postmodern writing subverting or contesting what it implies. Through conflating castration and decapitation and blurring their targets or mechanism, Carter moves beyond oppressive or patriarchal "Freudian" labels to better accommodate the inclusive, more flexible rhetoric of French feminism, poststructuralism, and postmodernism.

\section{References}

[1] Carter, A. (1979). The Bloody Chamber. In Burning Your Boats: The Collected Short Stories, Intro. Salman Rushdie, 111-143. New York: Henry Holt and Company, 1995.

[2] Carter, A. (1979). The Erl-King. In Burning Your Boats: The Collected Short Stories, Intro. Salman Rushdie, 186-192. New York: Henry Holt and Company, 1995.

[3] Carter, A. (1974). The Executioner's Beautiful Daughter. In Burning Your Boats: The Collected Short Stories, intro. Salman Rushdie, 35-40. New York: Henry Holt and Company.

[4] Castle, G. (2007). The Blackwell Guide to Literary Theory. Malden: Blackwell.

[5] Cixous, H. (1981). Castration or Decapitation?, trans. Annette Kuhn. Signs, 7(1), 41-55. http://www.jstor.org/stable/3173505. (accessed 23 September 2010).

[6] Cixous, H. (1976). The Laugh of the Medusa, trans. Keith and Paula Cohen. Signs, 1(4), 875-893. http://www.jstor.org/stable/3173239. (accessed 30 March 2017).

[7] Foucault, M. (1977). Discipline and Punish: The Birth of the Prison, trans. Alan Sheridan . New York: Vintage.

[8] Freud, S. (1925). Analysis of a Phobia in a Five-Year-Old Boy, trans. Alix \& James Strachey. www.mhweb.org. (accessed: 20 March 2020). [9] Freud, S. (1924). The Dissolution of the Oedipus Complex. In The Standard Edition of the Complete Psychological Works of Sigmund Freud, trans. James Strachey, 1923-1925. Vol. XIX. London: The Hogarth Press, 1961.

[10] Freud, S. (1940). Medusa's Head. In Standard Edition, trans. James Strachey. Vol. 18, 273-274. http://www.freud2lacan.com. (accessed: 21 October 2019).

[11] Freud, S. (1925). Some Psychological Consequences of the Anatomical Distinction between the Sexes. http://www.aquestionofexistence.com. (accessed: 7 October 2019).

[12] Hutcheon, L. (1987). The Politics of Postmodernism: Parody and History. Cultural Critique 5: 179-207. http://www.jstor.org. (accessed: 2 March 2020).

[13] Krifa, W. (2018). Angela Carter's The Bloody Chamber: A Hermeneutic Perspective. International Journal of Arts and Social Science, 1(4), 57-61. www.ijassjournal.com.

[14] Lacan, J. (1977). The Meaning of the Phallus. In The Critical Tradition: Classic Texts and Contemporary Trends, $3^{\text {rd }}$ ed., ed. David Richter, 1149-1155. Boston: Bedford/St. Martin's, 2007.

[15] Lacan, J. (1989). Écrits: A Selection, trans. Alan Sheridan. London: Routledge.

[16] Laurens, K. (2014). This White Rose: Virginity in The Bloody Chamber. The Cornithian, 15, Art. 5.

http://kb.gcsu.edu/thecornithian/vol15/iss1/5.

[17] Macsiniuc, C. (2015). Sartorial Rhetoric and Gender Roles in Angela Carter's The Bloody Chamber. Meridian Critic, 24(1), 79-91. http://www.diacronia.ro.

[18] Mohammadi, A., and J. Momeni. (2017). Non-Identity and Paradoxicality in Angela Carter's The Bloody Chamber. International Letters of Social and Humanistic Sciences, 75, 32-40. DOI: 10.18052/www.scipress.com/ILSHS.75.32.

[19] Rodríguez-Salas, G. (2010). No More Lullabies for Foolish Virgins: Angela Carter and 'TheErl-King'. English Studies (ES): Revista de Filología Inglesa, 31, 223-231. http://hdl.handle.net/10481/24898.

[20] Rubinson, G. J. (2000). 'On the Beach of Elsewhere': Angela Carter's Moral Pornography and the Critique of Gender Archetypes. Women's Studies, 29, 717-740.

[21] Rushdie, Salman. (1995). Introduction. In Burning Your Boats: The Collected Short Stories, by Angela Carter, ix-xiv. New York: Henry Holt and Company.

[22] Selden, R., et al. (2005). A Reader's Guide to Contemporary Literary Theory, $5^{\text {th }}$ ed. Harlow: Pearson.

[23] Spivak, G. C. (1988). Can the Subaltern Speak? In The Norton Anthology of Theory and Criticism, ed. Vincent B. Leitch, 2197-2208. New York: Norton, 2001.

[24] Tyson, L. (2006). Critical Theory Today: A User-Friendly Guide, $2^{\text {nd }}$ ed. New York: Routledge.

[25] Yazdizadeh, A. (2018). Lacan as a Reader of Angela Carter's The Bloody Chamber. Studies in Literature and Language, 16(2), 1-9. DOI: 10.3968/10145. 